Int. J. Electrochem. Sci., 15 (2020) 8960 - 8970

\title{
Characterization and Analysis of Chromium Coating Electrodeposited on Brass in ChCl-EG Deep Eutectic Solvent
}

\author{
Huixuan Qian, Qisong Li, Jie Sun", Souavang Xaikoua, Haijing Sun
}

School of Environmental and Chemical Engineering, Shenyang Ligong University, Shenyang, 110168, P. R. China

*E-mail: jiersun2000@,126.com

doi: $10.20964 / 2020.09 .03$

Received: 16 March 2020 / Accepted: 10 June 2020 / Published: 10 August 2020

Black chromium coating was electrodeposited on brass substrate from choline chloride-ethylene glycol (ChCl-EG) deep eutectic solvent (DES), via potentiostatic electrodeposition method. Cyclic voltammetry method was used to study the electrochemical reduction behavior of trivalent chromium ions $\left(\mathrm{Cr}^{3+}\right)$ in $\mathrm{ChCl}$-EG deep eutectic solvent. The composition and morphology of coating were characterized by X-ray photoelectron spectroscopy and scanning electron microscopy. The results showed that the electrochemical reduction of $\mathrm{Cr}$ (III) followed a two-step process, $\mathrm{Cr}$ (III) to $\mathrm{Cr}$ (II), and $\mathrm{Cr}(\mathrm{II})$ to $\mathrm{Cr}(0)$. Furthermore, the results indicated the existence of $\mathrm{Cr}$ and $\mathrm{O}$ elements in the coating, which was composed of chromium oxide, chromium hydroxide, and metallic chromium. Formation of the mixed phase was primarily caused by water molecules existing in the ChCl-EG deep eutectic solvent.

Keywords: Deep eutectic solvent; Chromium; Electrodeposition; Electrochemical reduction behavior; Morphology

\section{FULL TEXT}

(C) 2020 The Authors. Published by ESG (www.electrochemsci.org). This article is an open access article distributed under the terms and conditions of the Creative Commons Attribution license (http://creativecommons.org/licenses/by/4.0/). 